\title{
3-4 YAŞ GRUBU ÇOCUKLARDA BENLİK KAVRAMI VE EBEVEYN TUTUMLARININ CINSIYYTLER AÇISINDAN KARŞILAŞTIRILMASI
}

\author{
Öğr. Gör. Fatma KAYIM \\ İstanbul Gelişim Üniversitesi \\ fkayim@gelisim.edu.tr \\ https://orcid.org/ 0000-0002-6432-7059 \\ Doç. Dr. Muhammed AYAZ \\ İstanbul Doğuş Üniversitesi \\ mayaz@dogus.edu.tr \\ https://orcid.org/ 0000-0002-9715-3809
}

\section{ÖZ}

$\mathrm{Bu}$ araştırmada, okul öncesi eğitim kurumlarına devam eden 3-4 yaş arası çocukların ebeveyn tutumları ile benlik kavramları arasındaki ilişkinin incelenmesi amaçlanmıştır. Araştırma, İstanbul'da yer alan iki okul öncesi eğitim kurumunda öğrenim gören 60 çocuk ve ebeveynleri ile yürütülmüştür. Araştırmada, sosyodemografik bilgiler Kişisel Bilgi Formu ile, çocukların benlik kavramı Purdue Çocuklar İçin Benlik Kavramı Ölçeği ve ebeveyn tutumları Aile Hayatı ve Çocuk Yetiştirme Tutum Ölçeği (PARI) ile değerlendirilmiştir. Araştırma sonucunda erkek çocuklarda benlik kavramının kız çocuklara göre daha yüksek olduğu bulunmuştur. PARI Ölçeğinin Demokratik ve Eşitlik alt ölçeği puanları ile benlik kavramı arasında pozitif bir ilişki bulunmuştur. Buna karşılık Ev Kadınlığı Rolünü Reddetme, Aşırı Annelik, Geçimsizlik, Sıkı Disiplin alt ölçeği ile benlik kavramı arasında negatif yönde bir ilişki bulunmuştur. Benlik kavramının, bireyin gelişiminde kritik bir evre olduğu bilinen erken çocukluk döneminde cinsiyetler arasında farklılık gösterdiği ve ebeveyn tutumlarının benlik kavramını etkilediği düşünülmüştür.

Anahtar Kelimeler: Benlik Kavramı, Benlik Gelişimi, Ebeveyn Tutumu, Erken Çocukluk Dönemi, Cinsiyet 


\title{
A COMPARISON BETWEEN 3-4 YEARS OLD CHILDRENS' SELF EFFICACY AND PARENTAL ATTITUDE IN TERMS OF GENDER
}

\begin{abstract}
The purpose of this study is to investigate the relationship between the parental attitude and self-efficacy of kindergarten children. The research is conducted with 60 children aged 3-4, studying at two kindergarten schools in Istanbul, and their parents. While sociodemographic information is evaluated with Personal Information Form, self-efficacy of the children is interpreted with Purdue Self Concept Scale. In addition to this, parental attitudes are tested with Parental Attitude Research Instrument (PARI). According to the research, self-efficacy score of boys are higher than girls. As a result of the analysis, it has been found that there is a positive correlation between the PARI democracy and equality subscale and their self-efficacy. However, there is a negative correlation between the overprotection, marital conflict, rejection of the role of house wife, strictness and authoritarianism with the self- efficacy. It is concluded that the concept of self-efficacy is different between genders in early childhood, which is known to be a critical stage in the development of the individual, and that parental attitudes influence the concept of self-efficacy.
\end{abstract}

Keywords: Self Efficacy, Self-Concept Development, Parental Attitude, Early Childhood, Gender

\section{GÍRIŞ}

İnsan, varoluşundan bu yana varlığını anlama ve açıklama çabası içinde olmuştur. $\mathrm{Bu}$ nedenle benlik kavramı yalnızca psikoloji biliminin merak konusu olmakla sınırlı kalmamış diğer bilimler tarafından da araştırılmaya ve tanımlanmaya çalışılmıştır (Özen, 2012: 267-284). Bireyin tutum, duygu, alg1, değer ve davranışlarına ilişkin öz değerlendirmesi olarak tanımlanan benlik kavramını Köknel, kişinin kendisini tanıma ve değerlendirme biçimi olarak ifade etmiş, Lawrence bu kavramı davranışlarımızın ardındaki motivasyon, tepkilerimizin biçimini belirleyen bir güdü olarak ele almıştır (Gander \&Gardiner, 1993: 497; Köknel, 1999: 64; Lawrence, 2000: 65). Bu kavram çocukluk döneminden itibaren kişinin çevresindeki insanlarla kurduğu ilişkiler çerçevesinde şekil almakta ve kişinin kendisi ile ilgili değerlendirmelerinin yanı sıra dış dünyaya ilişkin algılarını da etkileyerek insanlarla ilişki kurma biçimine yansımaktadır.

Benlik kavramı zamanla gelişen ve dönüşüme uğrayan yavaş bir süreçtir. Benliğin oluşmasında kişinin bireysel deneyimlerine ilişkin yorumlarının yanı sıra başka 
kimselerle kurduğu etkileşimin de büyük bir rolü vardır. Birey büyüyüp geliştikçe, kendi varlı̆̆ının bilincine vardıkça yaşadığı çevre içindeki varlığından oluşan bir benlik geliştirmeye başlar (Cüceloğlu, 1997: 143; Cevher ve Buluş, 2007: 52-64; Piaget, 2004: 36-44). Yaşamın ilk yılları, bireyin dış dünya aracılığıyla kendisini tanıması ve kendisi ile ilgili bir algı oluşturmaya başlaması açısından oldukça önemlidir. Erken çocukluk döneminde ebeveynlerin çocukların dış dünya temsili olduğu düşünüldüğünde, benlik kavramı yetişkinlerin çocuğa yönelttikleri tutumların bir yansıması olarak karşımıza çıkmaktadır. Bu durumun bir sonucu olarak koşulsuz sevgi ortamında büyümenin çocuğun güçlü ve olumlu bir benlik kavramı geliştirmesini sağlayabileceği gibi ebeveynleri tarafından itici ve reddedici tutumlara maruz kalan çocukların değersizlik inançlarının artabileceği belirlenmiştir (Yavuzer, 2007: 26-28; Cüceloğlu, 2008: 347-400; Cevher ve Buluş, 2007: 64). Hoşgörülü ve demokratik evlerde büyüyen çocukların arkadaşlarıyla ilişkilerinde daha etkin, girişken, yaratıcı fikirler öne sürebilen, fikirlerini serbestçe söyleme eğiliminde olan, kendisini düzenleme ve denetleme becerisine de yaşıtlarına göre daha erken yaşta sahip olduğu saptanmıştır. Buna karşıllk katı ve otoriter bir disiplin yöntemi uygulanan ya da eğitim yöntemleri tutarsızlık ve değişkenlik gösteren ailelerde büyüyen çocukların ise kurallara uyum sağlamakta zorlanma ve saldırganlık gösterme gibi yollarla kendilerini kabul ettirmeye çalıştıkları ve kendi iç dünyalarını açıklamakta zorluk yaşadıkları ortaya çıkmıştır (Yavuzer, 2006: 130-138). Bandura ise benlik kavramı yüksek insanların hayatlarındaki çeşitli zorluklarla daha iyi başa çıkabildiklerini, bununla birlikte bu kişilerin başarılı olacaklarına dair inançlarının benlik kavramı düşük olan kişilere göre daha yüksek olduğunu ifade etmiş̧ir (Bandura, 1982: 114-131). Başka bir ifadeyle, benlik kavramının bireyin kendilik değerine ve yetkinlik inancına olan etkisi yalnızca çocukluk dönemini kapsamakla sınırlı kalmayarak bireyin yetişkinlik hayatında da etkisini devam ettirmektedir.

Ülkemizde gerçekleştirilen araştırmalar da yurtdışında yapılan çalışmaları destekler nitelik taşımaktadır. Yapılan çalışmalar incelendiğinde ebeveyn tutumunun çocuğun benlik kavramının gelişiminde göz ardı edilmemesi gereken bir etkiye sahip olduğu ortaya konmuştur. Aktaş'ın 9. sınıfta öğrenim gören öğrenciler ile gerçekleştirdiği çalışmanın sonucunda, lise öğrencilerinde algılanan demokratik anne baba tutum puanları arttıkça benlik saygılarının arttığ 1 , algılanan koruyucu ve otoriter anne baba tutum puanları arttıkça ise benlik saygılarının azaldığı belirlenmiştir. (Aktaş, 2011: 84). Filiz ve Yaprak'ın birlikte yürütmüş olduğu araştırmanın sonucunda ise benlik kavramı yüksek 671 öğrencinin \%3.7 otoriter, \%19 koruyucu, \%5.5 ilgisiz ve \%71.7 demokratik ebeveyn tutumuna sahip olduğu saptanmıştır (Filiz ve Yaprak, 2009: 201-205). Benlik kavramını etkileyen faktörlerin incelendiği bir diğer çalışmada ise anneden algılanan davranışsal kontrolün ergenlerin benlik kavramını artırdığı, 
buna karşıllk psikolojik kontrolün benlik kavramını olumsuz yönde etkilediği bildirilmiştir (Kındap vd. 2008: 98-104). Farklı araştırmalar da aile ortamındaki birlik ve beraberliğin çocukların öz saygı, öz yeterlilik ve benlik kavramlarını olumlu yönde etkilediği, aile ortamındaki denetimin ise çocukların öz saygı, öz yeterlilik ve benlik kavramlarını olumsuz yönde etkilediği belirlenmiştir (Yazıcı ve Taştepe, 2013: 103-108). Yapılan çalışmaların ortak bir sonucu olarak, çocuğun kontrol algısını destekleyen ve arttıran ebeveyn tutumlarının benlik kavramını ve yeterlilik inancını artırdığ 1 , buna karşılık çocuğun kendisini tanımasına izin verilmediği ve üzerinde kontrol geliştirilmeye çalışıldığı aşırı otoriter ve baskıcı ebeveyn tutumlarının çocuğun benlik kavramını olumsuz yönde etkilediği görülmüştür.

Cinsiyetin benlik kavramı üzerindeki etkisi ile ilgili alanyazını incelendiğinde, kız ve erkek çocuklara uygulanan öz yeterlilik ölçekleri sonucunda erkeklerin kızlardan anlamlı bir oranda daha yüksek öz yeterlilik puanı aldıkları, erkeklerin becerilerini abartılı bir şekilde algıladığı, buna karşılık kızların becerilerini küçümsediği belirlenmiştir (Ponsoda vd., 2008: 218-222; Furnham vd., 2001: 107-110). Bir diğer deyişle algılanan cinsiyet rollerinin çocukluktan itibaren bireyin kendisi ile ilgili değerlendirmesinde belirleyici etkenlerden birisi olduğu, bu etkinin kız çocuklarının kendi becerilerini tanımlamasına olumsuz yönde katkı yaparken erkek çocuklarının geliştirmesi gereken becerilerini tanımakta güçlük çektiği saptanmıştır.

Yazın incelendiğinde ebeveyn tutumu ile çocukların benlik kavramları arasındaki ilişki üzerine birçok araştırmanın yapılmış olduğu, ancak bu araştırmaların pek çoğunun okul çağı ve ergenlik dönemine yönelik olduğu, okul öncesi gruba yönelik çalışmaların kısıtlı kaldığ 1 saptanmıştır. Bu çalışmada, 3-4 yaş grubu çocukların benlik kavramlarının cinsiyet açısından karşılaştırılması ve ebeveyn tutumlarının çocukların benlik kavramı ile ilişkisinin incelenmesi amaçlanmıştır.

\section{YÖNTEM}

Çalışmaya, İstanbul ili Başakşehir ilçesinde yer alan iki farklı okul öncesi özel eğitim kurumunda öğrenim gören 3-4 yaş grubundaki 33'ü kız 27'si erkek olmak üzere toplam 60 öğrenci ve ebeveynleri alınmıştır. Fiziksel ya da ruhsal hastalıklar nedeniyle özürlü sağlık kurulu raporu olan çocuklar çalışmaya alınmamıştır. Araştırmada, Sosyodemografik Bilgi Formu, Purdue Çocuklar İçin Benlik Kavramı Ölçeği ve Aile Hayatı ve Çocuk Yetiştirme Tutum Ölçeği olmak üzere toplam üç ölçme aracı kullanılmıştır. 
Araştırmaya katılan çocukların yaşı, cinsiyeti, anne-babanın eğitim seviyesi, anne-babanın yaşı, birliktelik durumları, yakınlık durumları, ailedeki çocuk sayısı, ailede kaçıncı çocuk oldukları gibi bilgilerin yer aldığı Sosyodemografik Bilgi Formu çalışmacılar tarafından geliştirilmiştir. Araştırmada, katılımcıların benlik algıları 1974 yılında Cicirelli tarafından geliştirilen Purdue Çocuklar İçin Benlik Kavramı Ölçeği ile değerlendirilmiştir. Ölçekte toplam 40 madde yer almakta ve her bir maddede 2 adet resim bulunmaktadır. Bütün maddelerde olumlu olan resim 1, olumsuz olan ise 0 olarak puanlanarak çocuğun benlik kavramı puanı elde edilmektedir (Cicirelli, 1974). Testin Türkçe geçerlilik güvenirlilik çalışması ise 2010 yılında Özlem Sarıca tarafından yapılmıştır. Ölçeğin güvenirliliğine yönelik yapılan analizlerin sonucunda Spearman Brown ve Guttman iç tutarlılık katsayısı (.79) bulunmuştur (Sarıca, 2010: 83-84). Araştırmada, annelerin çocuk yetiştirme tutumları ise Aile Hayatı ve Çocuk Yetiştirme Tutum Ölçeği aracılığı ile belirlenmiştir. Bu ölçek Szhafer ve Bell tarafından 1958 yılında geliştirilmiş, ölçeğin Türkçe geçerlilik güvenirlilik çalışması ise Le Compte ve Özer tarafından 1978 yılında yapılmıştır. Yapılan geçerlilik güvenirlilik çalışmaları sonucunda ölçeğin orijinalini oluşturan 115 maddenin geçerlik ve anlaş1lırlığı yüksek 60 madde seçilerek 5 alt boyuttan meydana gelen ölçek oluşturulmuştur. Bu alt ölçekler aşırı annelik, demokratik tutum ve eşitlik tanıma, ev kadınlığı rolünü reddetme, geçimsizlik ve sıkı disiplindir. Aşırı annelik alt boyutunda 16 madde, ev kadınlığı rolünü reddetme alt boyutunda 13 , geçimsizlik alt boyutunda 6 , sık1 disiplin alt boyutunda ise 16 madde bulunmaktadır (Schafer ve Bell, 1958: 350361; Le Compte ve Özer, 1978: 5-8). Bu alt boyutlardan yüksek puan almak, olumsuz olarak değerlendirilmektedir. Demokratik tutum ve eşitlik tanıma alt boyutu ise 9 maddeden oluşmaktadır. Yalnızca bu alt boyuttan yüksek puan alınması olumlu olarak değerlendirilmektedir. Ölçek boyutlarındaki maddeler karışık olarak yer almaktadır. Maddeler olumlu veya olumsuz ifadeler şeklindedir ve dörtlü likert tipi bir ölçektir (Öner, 2008: 884-886). Purdue Çocuklar İçin Benlik Kavramı Ölçeği, araştırmacılar tarafından çocuklar ile gerçekleştirilen yüz yüze görüşmeler ile uygulanmış; Sosyodemografik Bilgi Formu ve Aile Hayatı ve Çocuk Yetiştirme Tutum Ölçeği araştırmaya dahil edilen çocukların anneleri tarafindan doldurulmuştur.

\section{İ̧̧LEM}

Çalışmanın yürütüldüğü eğitim kurumlarına devam eden 3-4 yaş grubundaki toplam 81 çocuğun ebeveynine çocuklarını eğitim kurumlarına bıraktıklarında yapılması planlanan araştırma ile ilgili bilgi verilmiştir. Çalışmaya katılmayı kabul eden 67 çocuğun ebeveyninden bilgi alınarak Sosyodemografik Bilgi Formu doldurulmuştur. Çocukların annelerinin doldurması amaciyla Aile Hayatı ve Çocuk Yetiştirme Tutum Ölçeği verilmiştir. Ölçekleri uygun şekilde doldurulan 
65 çocuğa çalışmacılar tarafindan Purdue Çocuklar İçin Benlik Kavramı Ölçeği uygulanmıştır. Ölçeğin uygulanmasına uyum sağlayamayan 5 çocuk çalışmadan çıkarılmıştır. Araştırma, katılımcıların zihinsel olarak aktif olduğu saatlerde yürütülmüştür. Her bir uygulama ortalama 20-25 dakika sürmüştür. Çalışmanın istatistiksel analizlerinde 60 katılımcının verileri değerlendirilmiştir.

Veri toplama araçlarından elde edilen veriler SPSS 17.0 istatistik programı ile analiz edilmiştir. Ölçek puanların çocukların cinsiyet gruplamasına göre normal dağılım gösterip göstermediği belirlemek amaciyla öncelikli olarak KolmogorovSmirnov testi uygulanmış, elde edilen sonuçlara bağlı olarak uygun istatistiksel analizler gerçekleştirilmiştir. İstatistik analizlerde, yüzde ve frekans dağılımı için Pearson Momentler Çarpımı Korelasyon Katsayısı testi kullanılmıştır. Bağımsız grupların ortalamalarını karşılaştırmak için ise Bağımsız Örneklemler T testi uygulanmıştır. Tüm istatistiksel hesaplamalarda anlamlılık düzeyi $p<.05$ olarak kabul edilmiştir.

\section{BULGULAR}

Öğrencilerin demografik özelliklerine ilişkin frekans ve yüzde hesapları Tablo 1'de gösterilmektedir. Araştırmanın örneklemini oluşturan çocukların \%56,7'ü 3 yaşında ve \%43,3'ü 4 yaşındadır. Bu öğrencilerin $\% 55$ 'i kız ve \%45'i erkektir. Öğrencilerin annelerin \%75'i ve babaların \%83,3’ü üniversite mezunudur. Araştırmaya katılan öğrencilerin annelerin \%96,7'si, babaların \%86,7'si 26-40 yaş grubunda yer almaktadır. Öğrencilerin \%90'nının anne-babası birlikteyken \%10'u boşanmış veya ayrı yaşamaktadır. Ailedeki çocuk sayısına bakıldığında, öğrencilerin \%41,7'si ailede tek çocukken, \%56,7'sinde iki çocuk ve sadece $\% 1,7$ 'sinde 3 çocuk olduğu belirlenmiştir. Araştırmaya katılan çocukların \%71,7'si ailede ilk çocuk, \%26,7'si ikinci çocuk ve \%1,7'si üçüncü çocuktur. Ayrıca araştırmaya katılan tüm çocukların anne-babaları hayatta olup ailelerinde bir kayıp durumu yaşanmadığı tespit edilmiştir. 
Tablo 1: Öğrencilerin demografik özelliklerine ilişkin frekans ve yüzde hesapları

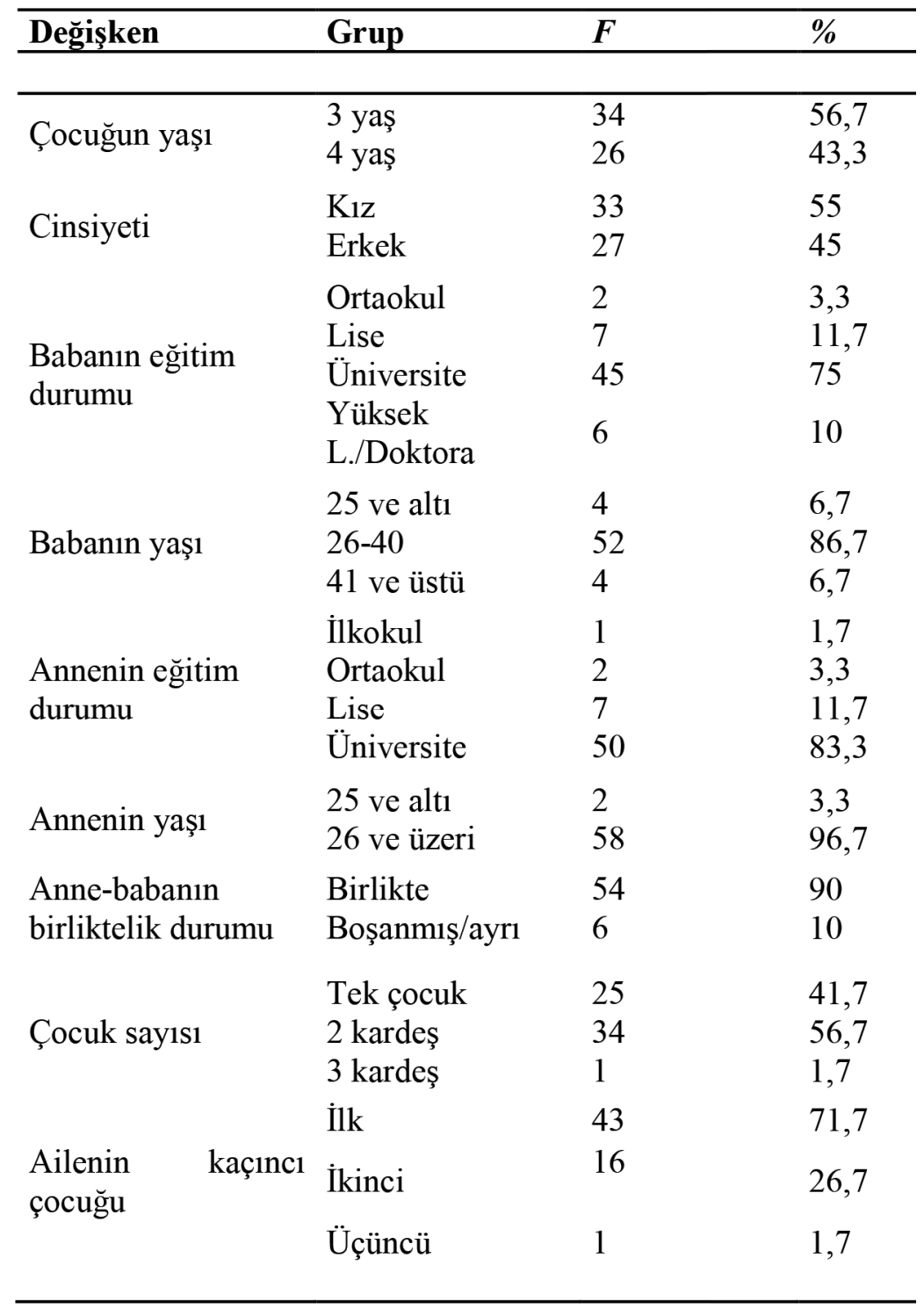


Purdue Çocuklar İçin Benlik Kavramı Ölçeği ve Aile Hayatı ve Çocuk Yetiştirme Tutum Ölçeği alt ölçeklerinin cinsiyet değişkenine göre normallik varsayımını karşıladığı yapılan Kolmogorov- Simirnov testi sonucunda belirlenmiştir ( $p>$ .05). Elde edilen sonuca bağlı olarak benlik kavramı düzeylerinin cinsiyete göre değişkenlik gösterip göstermediğini bulabilmek için İki Bağımsız Örneklemler t Testi kullanılmıştır. Analiz sonuçları Tablo 2'de yer almaktadır.

Tablo 2: Çocukların benlik kavramı düzeylerinin cinsiyetlere göre karş1laştırılması

\begin{tabular}{|c|c|c|c|c|c|c|c|c|}
\hline \multirow{2}{*}{ Ölçek } & \multirow{2}{*}{ Cinsiyet } & \multicolumn{4}{|c|}{ Betimsel İstatistikler } & \multicolumn{3}{|c|}{ T-test } \\
\hline & & $\mathbf{N}$ & $\overline{\bar{X}}$ & Ss & $\mathbf{S}_{\mathrm{h}}$ & $\mathbf{T}$ & Sd & $\mathbf{P}$ \\
\hline Benlik & $\mathrm{K}_{1 \mathrm{z}}$ & 33 & 33,58 & 5,1 & 0,89 & 2,71 & 58 & $0,009 *$ \\
\hline Kavramı & Erkek & 27 & 36,56 & 2,86 & 0,55 & & & \\
\hline
\end{tabular}

${ }^{*}$ Fark $p<.05$ dïzeyinde anlamlidir.

Tablo 2'de belirtildiği gibi, çocukların benlik kavramına ilişkin algılarının cinsiyet değişkenine göre istatistiksel olarak anlamlı bir biçimde farklılaştı̆̆ 1 ve bu farkın erkek ögrenciler lehine olduğu bulunmuştur $\left[\mathrm{t}_{(58)}=2,71 ; \mathrm{p}<, 05\right]$. Öğrencilerin ortalama puanları incelendiğinde, erkek çocukların benlik kavramı ortalamalarının kız çocuklarından daha yüksek olduğu saptanmıştır $\left(\bar{X}_{K ı z}=33,58\right.$; $\bar{X}_{\text {Erkek }}=36,56$ ).

Tablo 3: Çocukların anne baba tutumları ile benlik kavramı arasındaki ilişki

\section{Alt Ölçek}

Aşırı annelik

Demokratik tutum ve

eşitlik tanıma

Ev kadınlığı rolünü

reddetme

Geçimsizlik

Sıkı disiplin

$\begin{array}{ll}\mathrm{R} & -0,648^{* *} \\ \mathrm{P} & <0,001 \\ \mathrm{R} & 0,714^{* *} \\ \mathrm{P} & <0,001 \\ \mathrm{R} & -0,282^{* *} \\ \mathrm{P} & 0,002 \\ \mathrm{R} & -0,285^{*} \\ \mathrm{P} & 0,027 \\ \mathrm{R} & -0,279^{*} \\ \mathrm{P} & 0,031\end{array}$

Benlik Kavramı

$(n=60)$

**illişki (korelasyon) 0,01 düzeyinde anlamlidrr.

*ilişki (korelasyon) 0,05 düzeyinde anlamlidir. 
Tablo 3’te belirtildiği gibi Purdue Çocuklar İçin Benlik Kavramı Ölçeği ile Aile Hayatı ve Çocuk Yetiştirme Tutumu alt ölçekleri arasındaki ilişkiyi belirlemek üzere Pearson Momentler Çarpımı Korelasyon Katsayısı Testi'nden yararlanılmıştır. $\mathrm{Bu}$ testin sonucunda Benlik Kavramı puanları ile tüm Aile Hayatı ve Çocuk Yetiştirme Tutumu alt ölçekleri puanlarının arasında istatistiksel olarak anlamlı bir ilişki bulunmuştur. Bu ilişki, Benlik Kavramı ve Demokratik Tutum ve Eşitlik Tanıma alt ölçeği arasında pozitif yöndedir $(r=0,714 ; p<0,01)$. Buna karşılık, Aşırı Annelik ( $r=-0,648 ; p<0,01)$, Ev Kadınlığı Rolünü Reddetme $(r=-0,282 ; p<0,01)$, Geçimsizlik $(r=-0,285 ; p<0,05)$ ve S1k1 Disiplin $(r=-0,279$; $p<0,05)$ alt ölçek puanları ile benlik kavramı puanları arasında negatif yönde istatistiksel olarak anlamlı bir ilişki olduğu tespit edilmiştir.

\section{TARTIŞMA}

Bu çalışmada, 3-4 yaş grubu çocukların benlik kavramına ilişkin algılarının cinsiyete göre farklılıkları çalışılmıştır. Ayrıca ebeveyn tutumlarının çocukların benlik kavramları üzerindeki etkisi incelenmiştir. Erken çocukluk dönemi, benlik kavramı gelişiminde oldukça önemli bir evredir. Olumlu bir benlik kavramı çocukların sosyal, akademik ve davranışsal gelişimi için gereklidir. Bu nedenledir ki benlik kavramı ile çeşitli değişkenlerin ilişkisi yazında pek çok kez incelenmiştir. Benlik kavramının cinsiyet açısından karşılaştırıldığı çalışmalar incelendiğinde sonuçların tartışmalı olduğu görülmektedir. Bazı çalışmalarda cinsiyet açısından belirgin farklılık bulunmazken (Ogelman ve Topaloğlu, 2014: 246- 255; Ogelman vd., 2013: 433-436), erkeklerde (Aşç1, 2004: 43-47; Aypay, 2010: 123-127 ) ve kızlarda (Gizir ve Baran, 2003: 120-127) benlik kavramını daha yüksek bulan çalışmalar vardır.

Benlik kavramı gelişirken kültürel özelliklerin ve çocukların yetiştirilme biçimlerinin önemli olduğu birçok çalışmada bildirilmektedir (Cooper ve Denner, 1998: 564-568; Endendijk vd., 2016: 15-23). Son dönemlerde yapılan çalışmalarda benlik kavramının cinsiyete göre anlamlı bir şekilde değişmemesinin nedeninin ise ebeveynlerin disiplin biçimlerinin biyolojik cinsiyete göre farklılaşmamasından kaynaklandığı düşünülmektedir (Zastrow, 2016: 596). Çalışmamızda erkek çocuklarda benlik kavramı daha yüksek bulunmuştur. Fakat bu durumun nedenini açılayacak yeterli sosyodemografik değişken değerlendirilmemiştir. Ancak erkek çocuklardaki benlik kavramı yüksekliğinin ebeveyn tutumlarının cinsiyete göre farklılaşmasından kaynaklanabileceği düşünülmektedir.

Benlik gelişimi okul öncesi dönemde başlamasına karşın etkisi diğer gelişim aşamalarında da devam etmektedir. Dolayısıyla olumsuz benlik gelişimi yaşamın farklı dönemlerinde farklı etkilere neden olabilmektedir. Benlik gelişiminin kendilik değeri ile yakından ilişkili olduğu göz önünde bulundurulduğunda 
olumsuz benlik gelişiminin ergenlik döneminde depresyon ve öz kıyım girişimlerini arttırdığını ortaya koyan çalışma sonuçları beklentiler ile uygunluk göstermektedir (Kocayörük, 2012: 28-31; Özcan vd., 2013: 109-111; Çivitçi, 2010: 145-149). Bu sonuçlar ışı̆̆ında benlik kavramına yönelik değerlendirme ve bu açıdan risk altındaki çocuklara yönelik önlemlerin okul öncesi dönemden itibaren alınmaya başlanmasının gerektiğini düşündürmektedir. Ebeveyn tutumları ilk toplumsal ilişki temsilleri olması açısından çocukların gelişimde belirleyici bir rol oynamaktadır. Farklı yaş gruplarında ebeveyn tutumu ve benlik kavramı arasındaki ilişkinin incelendiği birçok çalışmada, demokratik tutum sergileyen ebeveynlerin çocuklarının benlik kavramının olumlu yönde geliştiği (Musaağaoğlu ve Güre, 2005: 86-90; Yazıc1 ve Taştepe, 2013: 101-106; Özen, 2009: 31-35; Kocayörük, 2012: 28-31), buna karş1lık ihmalkâr, reddedici ve aşırı otoriter tutum gösteren ebeveynlerin çocuklarının benlik kavramı gelişimini olumsuz yönde etkilediği belirlenmiştir (Niditch ve Varela, 2012: 27-31; Warash ve Markstrom, 2001: 489-492; Brodski ve Hutz, 2012: 265-270; Nishikawa, Sundbom ve Hagglof, 2010: 60-64). Ortaya konulan bu etki yaşamın birçok farklı alanında kendini göstermekte, bireyin duyguları, görüşleri tutum ve davranışlarına yansıdığı görülmektedir.

Çalışmamızın sonuçları, 3-4 yaş grubundaki çocuklarda da ebeveyn tutumları ile benlik kavramı arasındaki ilişkinin önemine dikkat çekmektedir. Demokratik ebeveyn tutumlarının çocukların benlik kavramları üzerinde olumlu bir etkisinin olduğu belirlenmiştir. Benlik kavramı üzerine ebeveyn tutumunun etkisini değerlendiren ve farklı yaş gruplarında yapılan çalışmalarla benzer şekilde 3-4 yaş grubu çocuklarda ev kadınlığı rolünü reddetme, aşırı annelik, geçimsizlik ve sıkı disiplinin çocukların benlik kavramını olumsuz etkilediği saptanmıştır. Çalışmamızın sonuçları, ebeveyn tutumlarının küçük yaşlardan itibaren çocukların benlik kavramını etkilemeye başladığını ve bu etkilerin 3-4 yaş grubunda da görünür hale geldiğini düşündürmektedir.

\section{SONUÇ}

Kişinin kendisi ile ilgili değerlendirmesi olarak tanımlanan benlik kavramı, doğum ile birlikte gelişmeye başlayarak yaşamın ilerleyen dönemlerinde de değişmeye devam eder. Olumlu bir benlik kavramı çocukların sosyal, akademik ve davranışsal gelişiminin sağlıklı bir biçimde gerçekleşmesi için gereklidir. $\mathrm{Bu}$ nedenle benlik gelişiminde etkili olan faktörleri belirlemek oldukça önemlidir. $\mathrm{Bu}$ faktörler arasında en önemlilerinden biri ise ebeveynlerin çocuk yetiştirmede izlediği yoldur. Henüz kendisini tanıma ve ayrı bir varlık olarak anlamlandırma sürecinde olan çocuğun ebeveynleri ile kurduğu etkileşim, onun ev içerisindeki konumunu belirleyeceği gibi, kendisi ile ilgili düşünce ve algısını da etkileyecektir. Alanyazını incelendiğinde ebeveyn tutumlarının benlik kavramı gelişimi 
üzerindeki etkisi pek çok kuramcı tarafından ortaya konulmuş olmasına karşıın erken çocukluk dönemini kapsayan araştırmaların sınırlı olduğu görülmüştür. $\mathrm{Bu}$ nedenle yapılan araştırmada, okul öncesi eğitim kurumlarına devam eden 3-4 yaş arası çocukların ebeveyn tutumları ile benlik kavramları arasındaki ilişki cinsiyetler arasındaki farklılıkları da ele alarak incelenmeye çalışılmıştır.

Araştırma sonucunda, benlik kavramı ve ebeveyn tutumları arasında anlamlı bir ilişki olduğu belirlenmiş̦tir. Ebeveyn tutumları Ev Kadınlığı Rolünü Reddetme, Aşırı Annelik, Geçimsizlik, Sıkı Disiplin, Demokratik ve Eşitlik boyutlarında incelenmiştir. Söz konusu ilişkiler incelendiğinde Demokratik ve Eşitlik tutum ile benlik kavramı arasında pozitif, Ev Kadınlığı Rolünü Reddetme, Aşırı Annelik, Geçimsizlik ve Sıkı Disiplin tutumları ile benlik kavramı arasında negatif yönde bir iliş̧inin olduğu belirlenmiştir. Elde edilen sonuçlar ebeveyn tutumlarının benlik algısını üzerindeki etkisini değerlendiren farklı yaş grupları ile yapılmış çalışmalar ile benzer sonuç göstermiştir. Çalışmamızın sonuçları, ebeveyn tutumlarının küçük yaşlardan itibaren çocuklarının benlik kavramını etkilemeye başladığını ve bu etkilerin 3-4 yaş grubunda da görünür hale geldiğini düşündürmüştür. Araştırmada elde edilen bir diğer sonuç ise benlik kavramının cinsiyetler açısından değişkenlik gösterdiğine, bu değişikliğin erkeklerin lehine olduğuna ilişkindir. Bu bulguyu açılayacak yeterli sosyodemografik değişkenler çalışmada değerlendirilmemiş olsa da, erkek çocuklardaki benlik kavramı yüksekliğinin ebeveyn tutumlarının cinsiyete göre farklılaşmasından kaynaklanabileceği düşünülmüştür. Araştırma bulguları değerlendirildiğinde benlik kavramının, bireyin gelişiminde kritik bir evre olduğu bilinen erken çocukluk döneminde, cinsiyetler arasında farklılık gösterdiği ve ebeveyn tutumlarının benlik kavramını etkilediği düşünülmüştür.

\section{KAYNAKÇA}

Aktaş, S. 9. Sinıfta Anne Baba Tutumları ve Benlik Saygısı Arasındaki İlişkinin Bazı Değişkenler Açısından Incelenmesi. Yüksek Lisans Tezi. Selçuk Üniversitesi/ Fen Bilimleri Enstitüsü, İstanbul, s. 84, 2011.

Aşçı, H. Fiziksel Benlik Algisının Cinsiyete ve Fiziksel Aktivite Düzeyine Göre Karşılaştırılması. Spor Bilimleri Dergisi, 15(1): 43-47, 2004.

Aypay, A. Genel Öz Yeterlik Ölçeği'nin Türkçeye Uyarlama Çalışması. İnönu Universitesi Eğitim Fakültesi Dergisi, 11 (2): 123-127, 2010.

Bandura, A. Self-Efficacy Mechanism in Human Agency. Amerikan Psychologist, 37(2): 122-147, 1982. 
Brodski, S.K. \& Hutz, C.S. The Repercussions of Emotional Abuse and Parenting Styles on Self-Esteem, Subjective Well- Being: A Retrospective Study with University Students in Brazil. Journal of Aggression, Maltreatment \& Trauma, 21: 265-270, 2012.

Cevher, F.N. \& Buluş, M. Benlik Kavramı ve Benlik Saygısı: Önemi ve Geliştirilmesi. Akademik Dizayn, 2: 52-64, 2007.

Cicirelli, V.G. Purdue Self-Concept Scale for Preschool Children. West Lafayetta, Purdue University, 1974.

Cooper, C.R. \& Denner, J. Theorles Linking Culture and Psychology: Universal and Community-Specific Processes. Annual Review of Psychology, 49: 564-568, 1998.

Cüceloğlu, D. İnsan ve Davranış: Psikolojinin Temel Kavramları. 14. baskı. Remzi Kitapevi, İstanbul, s. 347-400, 2008.

Cüceloğlu, D. İçimizdeki Çocuk. 17. baskı. Remzi Kitabevi, İstanbul, s. 143, 1997.

Çivitçi, A. Moderator Role of Self-Esteem On The Relationship Between Life Satisfaction and Depression in Early Adolescents. Emotional \& Behavioural Diffuculties, 15(2): 145-149, 2010.

Endendijk, J.J., Groeneveld, M.G., Kranenburg, M.J. \& Mesman, J. GenderDifferentiated Parenting Revisited:Meta-Analysis Reveals Very Few Differencesin Parental Control of Boys and Girls. Plos One, 11(7):15-23, 2016. doi: 10.7910/ DVN/P6X6XC

Filiz, Z. \& Yaprak, B. Diskriminant Analiziyle Anne Baba Tutumlarının Sinıflandırılmasına İlişkin Bir Uygulama. Eğitimde Kuram ve Uygulama. 5(2): 195-209, 2007.

Furnham, A., Hosoe, T. \& Tang, T. Male Hubris and Female Humility? A Crosscultural Study of Ratings of Self, Parental, and Sibling Multiple Intelligence in America, Britain and Japan. İntellegence, 30 (1): 101-115, 2001.

Gander, M.J. \& Gardiner, H.W. (Ed.). Çocuk ve Ergen Gelişimi, 4. baskı. İmge, Ankara, s. 497, 2001.

Gizir, Z. \& Baran, G. Anaokuluna Devam Eden 4-5 Yaş Çocuklarında Sosyal Davranışların Gelişimi ile Benlik Saygısı Arasındaki İlişkinin İncelenmesi. Çukurova Üniversitesi Eğitim Fakültesi Dergisi, 2(25):120-127, 2003. 
Kındap, Y., Sayıl, M. \& Kumru, A. Anneden Algllanan Kontrolün Niteliği ile Ergenin Psikososyal Uyumu ve Arkadaşlıkları Arasındaki İlişkiler: Benlik Değerinin Aracı Rolü. Türk Psikoloji Dergisi, 23 (61): 92-107, 2008.

Kocayörük, E. Öz-Belirleme Kuramı Açısından Ergenlerin Anne Baba Algısı ile Duyuşsal L̇yi Oluşları Arasındaki İlişki. Türk Psikolojik Danışma ve Rehberlik Dergisi, 4(37): 28-31, 2012.

Köknel, Ö. Kaygıdan Mutluluğa Kişilik. 15 baskı. Akdeniz, s. 64, 1999.

Lawrence, Denis, "Building Self-esteem With Adult Learners", Paul Chapman Publishing, 1. Publishhed, London, Great Britain, s.65, 2000.

Le Compte, G., Le Compte, A. \& Özer, S. (1978). Üç Sosyoekonomik Düzeyde Ankaralı Annelerin Çocuk Yetiştirme Tutumları: Bir ölçek uyarlaması. Türk Psikoloji Dergisi, 1(1): 5-8.

Musaağaoğlu, C. \& Güre, A. Ergenlerde Davranışsal Özerklik ile Algllanan AnaBaba Tutumları Arasındaki Illişkiler. Türk Psikoloji Dergisi, 20(55): 86-90, 2005.

Niditch, L.A., \& Varela, R.E. Perceptions of Parenting, Emotional Self-Efficacy and Anxiety in Youth: Test of a Mediational Model. Child and Youth Care Forum, 41: 27-31, 2012. doi: 10.1007/s10566-011-9150-x

Nishikawa, S., Sundbom, E. \& Hagglof, B. Influence of Perceived ParentalRearing on Adolescent Self-Concept and Internalizing and Externalizing Problems in Japan. Journal of Child and Famıly Studies, 19: 60-64, 2010. doi: 10.1007/s 1026-009-9281-y

Ogelman, H.G., Topaloğlu, Z.Ç. 4-5 Yaş Çocuklarının Sosyal Yetkinlik, Saldirganlık, Kaygı Düzeyleri ile Anne-Babalarının Ebeveyn Özyeterliği Algısı Arasındaki İlişkilerin Incelenmesi. Abant İzzet Baysal Üniversitesi Eğitim Fakültesi Dergisi,14(1): 246-255, 2014.

Ogelman, H.G., Seçer, Z. \& Önder, A. Analyzing Perspective Taking Skills of 5- to 6-Year-Old Preschool Children in Relation to Their Self-Perception and Gender. Journal of Research in Childhood Education, 27: 433-436, 2013. do1: $10.1080 / 02568543.2013 .822951$

Öner, N. Türkiye'de Kullanılan Psikolojik Testler. 2. baskı. Boğaziçi, İstanbul, s. 884-886, 2008.

Özcan, H., Subaşı, B., Budak, B., Çelik, B.M., Gürel., Ş.C. \& Yı1dız, M. Ergenlik ve Genç Yetişkinlik Dönemindeki Kadınlarda Benlik Saygısı. Sosyal Görünüş Kaygısi, Depresyon ve Anksiyete Iliş̧kisi. Journal of Mood Disorders, 3(3): 109111, 2013. do1: 10.5455/jmood.20130507015148 
Özen, D. Ş. Ergenlerde Anneden Algılanan Kabul/İlgi ile Benlik-Alglsı Arasındaki İlişki: Babadan Algılanan Kabul/İlginin Aracı Rolü. Türk Psikoloji Yazıları, 12(24): 31-35, 2009.

Özen, Y. Varoluşçu Felsefeden Varoluş̧̧u Psikolojiye (Birbirlerini Sürekli Yanlış Anlayanların Ontolojik Bütünlüğ̈̈). Gümüşhane Üniversitesi Sosyal Bilimler Elektronik Dergisi, 5: 267-286, 2012.

Piaget, J. Çocukta Zihinsel Gelişim. 2. baskı. (Hüseyin Portakal Çev.). Cem Psikoloji, İstanbul, s. 36-44, 2004.

Ponsodo, V., Abad, F.J., Francis, L.J. \& Hills, P.R. Gender Differences in the Coopersmith Self- Esteem Inventory. Journal of Individual Differences, 29: 217222, 2008. doi:10.1027/1614-0001.4.217

Sarıca, Ö. (2010). Okul Öncesi Ĕ̆itim Kurumlarına Devam Eden 5 ve 6 Yaş Grubu Çocuklarının Benlik Kavramlarının Çeşitli SosyoDemografik Değişkenlere Göre İncelenmesi. (Yayımlanmamış yüksek lisans tezi) Maltepe Üniversitesi/Sosyal Bilimler Enstitüsü, İstanbul, s. 83-84, 2010.

Schafer, E.S. \& Bell, R.Q. Development of A Parental Attitude Research Instrument. Child Development, 29: 350-361, 1958.

Warash, B.G. \& Markstrom, C.A. Parental Perception of Parenting Styles in Relation to Academic Self- Esteem of Preschoolers. Child Development and Family Studies. 121(3): 489- 492, 2001.

Yavuzer, H. Çocuk Psikolojisi. 29. baskı. Remzi Kitapevi, Ankara, s. 130-138, 2006.

Yavuzer, H. Çocuğu Tanımak ve Anlamak. 6. bask1. Remzi, İstanbul. 26-28, 2007.

Yazıcı, Z. \& Taştepe, T. Ebeveynlerin Aile Ortamı Algısı ile Çocukların Benlik Algisl Arasındaki Illişki. International Journal of Human Science, 10(2): 101-106, 2013.

Zastrow, C. (Ed.) Sosyal Hizmete Giriş. 4. baskı. (Aslıhan Aykara vd. Çev.). Nika, Ankara, s. 596, 2016. 